\title{
Specify if Present
}

National Cancer Institute

\section{Source}

National Cancer Institute. Specify if Present. NCI Thesaurus. Code C159216.

A request to specify if present. 